\title{
Assessment of the Deep Sea Wreck USS Independence
}

\author{
James P. Delgado ${ }^{1}$, Lisa C. Symons ${ }^{1 *}$, Kelley Elliott ${ }^{2}$, Frank Cantelas ${ }^{2}$ and \\ Robert V. Schwemmer ${ }^{3}$
}

${ }^{1}$ Office of National Marine Sanctuaries, National Oceanic and Atmospheric Administration, Silver Spring, MD, USA, ${ }^{2}$ Office of Ocean Exploration and Research, National Oceanic and Atmospheric Administration, Silver Spring, MD, USA, ${ }^{3}$ Maritime Heritage Program, NOAA's Office of National Marine Sanctuaries, National Oceanic and Atmospheric Administration, Santa Barbara, CA, USA

\section{OPEN ACCESS}

Edited by:

Nikolaos P. Ventikos, National Technical University of Athens, Greece

Reviewed by: Natalia Ospina-Alvarez, Universität Potsdam, Germany

Stefanos Magoulas,

Environmental Consultant - Surveyor,

Greece

*Correspondence:

Lisa C. Symons

lisa.symons@noaa.gov

Specialty section: This article was submitted to Marine Pollution, a section of the journa Frontiers in Marine Science

Received: 23 January 2016 Accepted: 12 May 2016 Published: 12 July 2016

Citation: Delgado JP, Symons LC, Elliott K, Cantelas F and Schwemmer RV (2016) Assessment of the Deep Sea Wreck USS Independence.

Front. Mar. Sci. 3:80. doi: 10.3389/fmars.2016.00080
As part of ongoing efforts to better understand the nature of shipwrecks in National Marine Sanctuaries which may pose some level of pollution risk, and in this case, to definitively locate what is likely the only shipwreck in a sanctuary involved in both nuclear testing and nuclear waste disposal, NOAA's Office of National Marine Sanctuaries collaborated with NOAA's Office of Ocean Exploration and The Boeing Company, which provided their autonomous underwater vehicle, Echo Ranger, to conduct the first deep-water archeological survey of the scuttled aircraft carrier USS Independence in the waters of Monterey Bay National Marine Sanctuary (MBNMS) in March 2015. The presence of the deep-sea scuttled "radioactive" aircraft carrier USS Independence off the California coast has been the source of consistent media speculation and public concern for decades. The survey confirmed that a sonar target charted at the location was Independence, and provided details on the condition of the wreck, and revealed no detectable levels of radioactivity. At the same time, new information from declassified government reports provided more detail on Independence's use as a naval test craft for radiological decontamination as well as its use as a repository for radioactive materials at the time of its scuttling in 1951. While further surveys may reveal more, physical assessment and focused archival work has demonstrated that the level of concern and speculation of "danger" from either a radioactive or oil pollution threat posed may be exaggerated.

Keywords: survey, pollution, shipwreck, autonomous underwater vehicles, nuclear, deep-water, cold war

\section{INTRODUCTION}

\section{USS Independence in World War II}

Independence was the first vessel of a new class of light aircraft carrier, (Lambert, 2015: 16, 136-137). Laid down in May 1941, Independence was launched on February 12, 1942, and commissioned on January 14, 1943 (Figure 1). The ship served with distinction throughout the Pacific War (Lambert, 2015:868). While serving in postwar "Magic Carpet" service ferrying troops back to the United States, on January 22, 1946 Independence received new orders re-tasking her for use as a target vessel in upcoming tests of the atomic bomb at Bikini Atoll in the Marshall Islands in July 1946 (Lambert, 2015: 760).

Two detonations of a Mk III "Fat Man" implosion-type plutonium core weapon, one air dropped, the other fired from a sealed underwater chamber, took place on July 1 and July 25. 


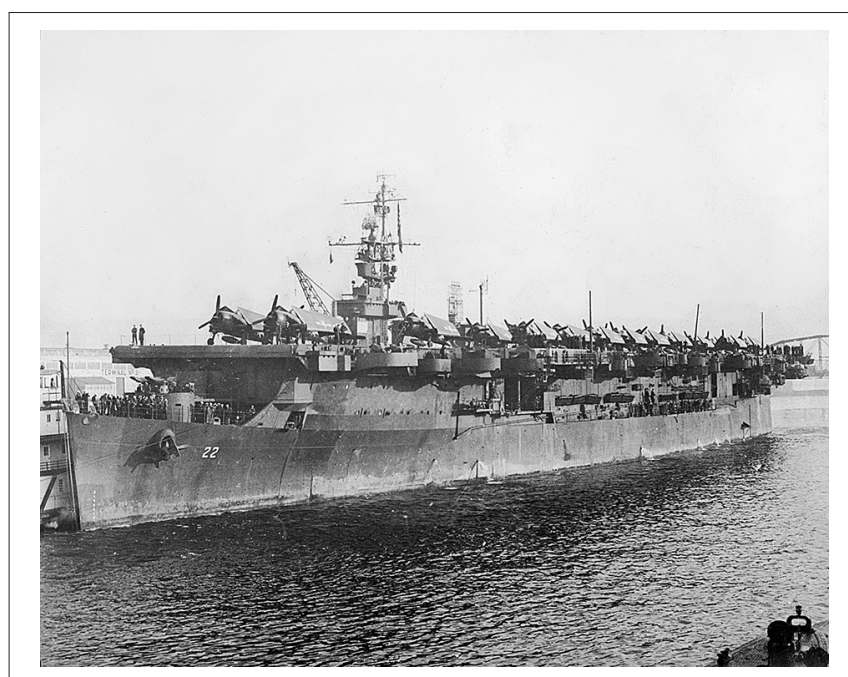

FIGURE 1 | USS Independence in harbor, c. 1943 (U.S. National Archives).
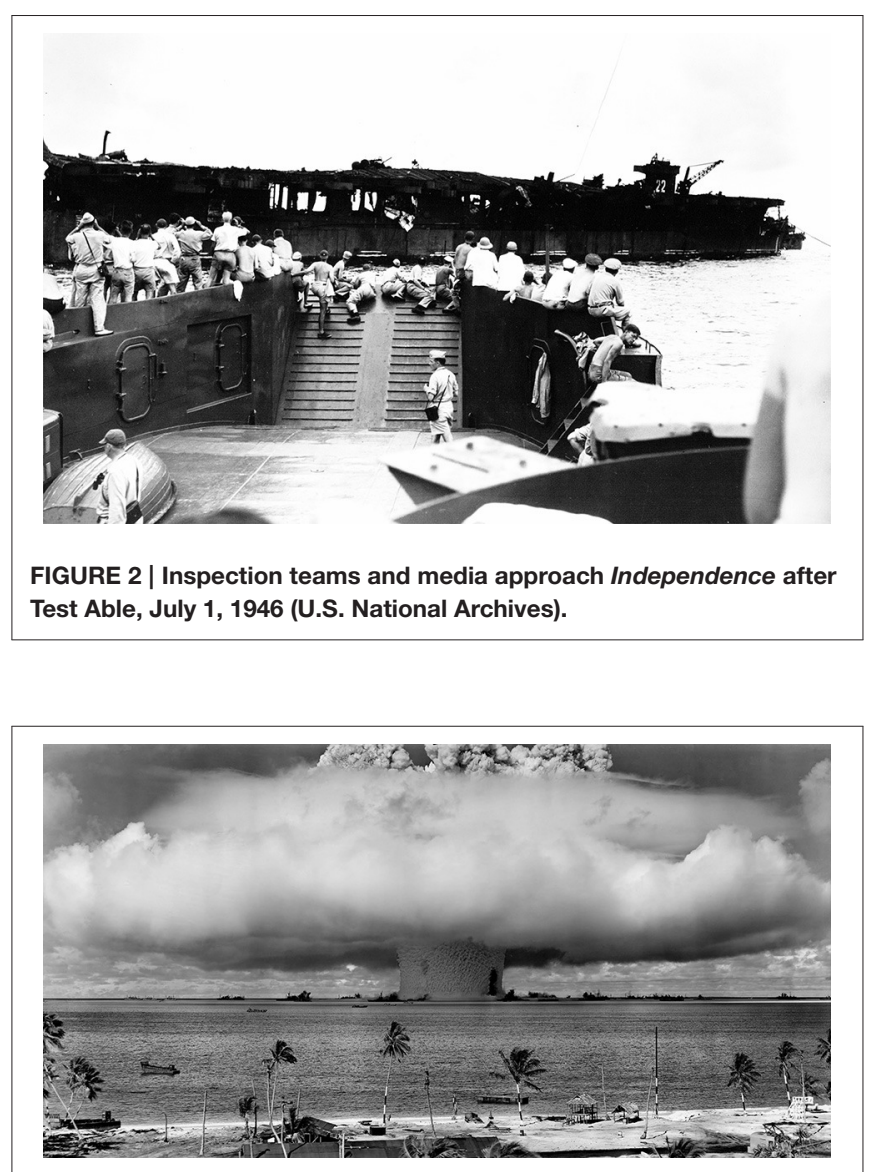

FIGURE 3 | Test Baker, Bikini, July 25, 1946 (U.S. National Archives).

techniques..." (as cited in Delgado et al., 1991: 31). Independence left Kwajalein under tow May 15, 1947, and arrived at Hunter's Point Naval Shipyard in San Francisco, on June 16, 1947 (Figures 4, 5; Delgado, 2016a).

After arriving at the shipyard, Independence served as the platform for the U.S. Navy's radiological decontamination school, later called the Naval Radiological Defense Laboratory until December 1950. Surface readings of radiation on arrival in San Francisco had declined to 0.060 REM per $24 \mathrm{~h}$. That reading (60 millirem) is now obsolete, but an average mammogram is calculated to be 30 millirem, according to the Environmental Protection agency (http://www.epa.gov/radiation/understand/perspective.html).

The Navy had previously decided to remove Independence's power plant, clearing out the engine and fire (boiler) rooms. A survey of the spaces found that they met "the requirements for final radiological clearance" and workers were allowed access to start work in January 1949. Once cleared, this space inside the hull was designated as a depository for "radioactive waste." Confirming this information was critical to understanding whether the ship could still also retain fuel oil and bunkers.

Radioactive waste placed in the ship included "samples collected from Crossroads target vessels" such as "every type of material found on the target vessels" ranging in size "from five 


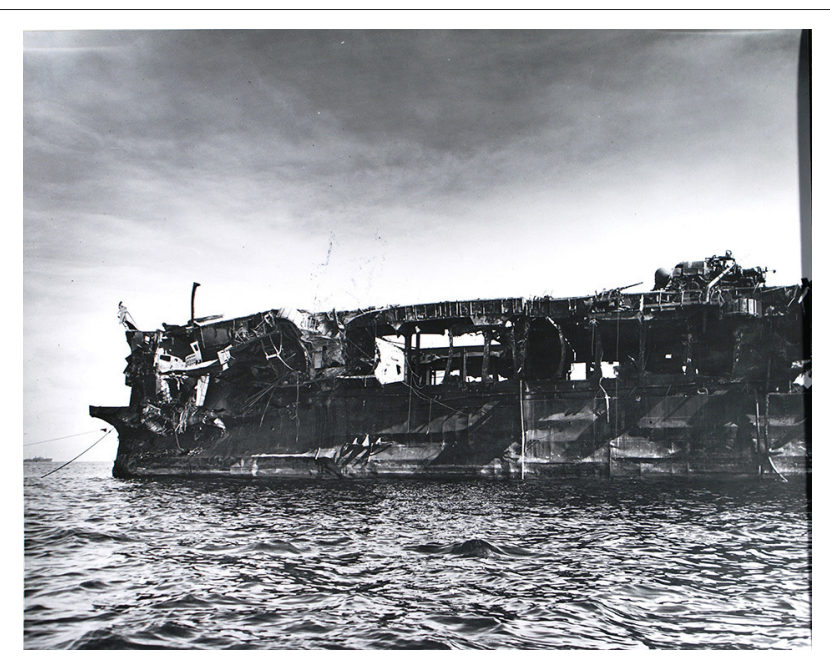

FIGURE 4 | Damage to USS Independence, documented after Operation Crossroads (U.S. National Archives).

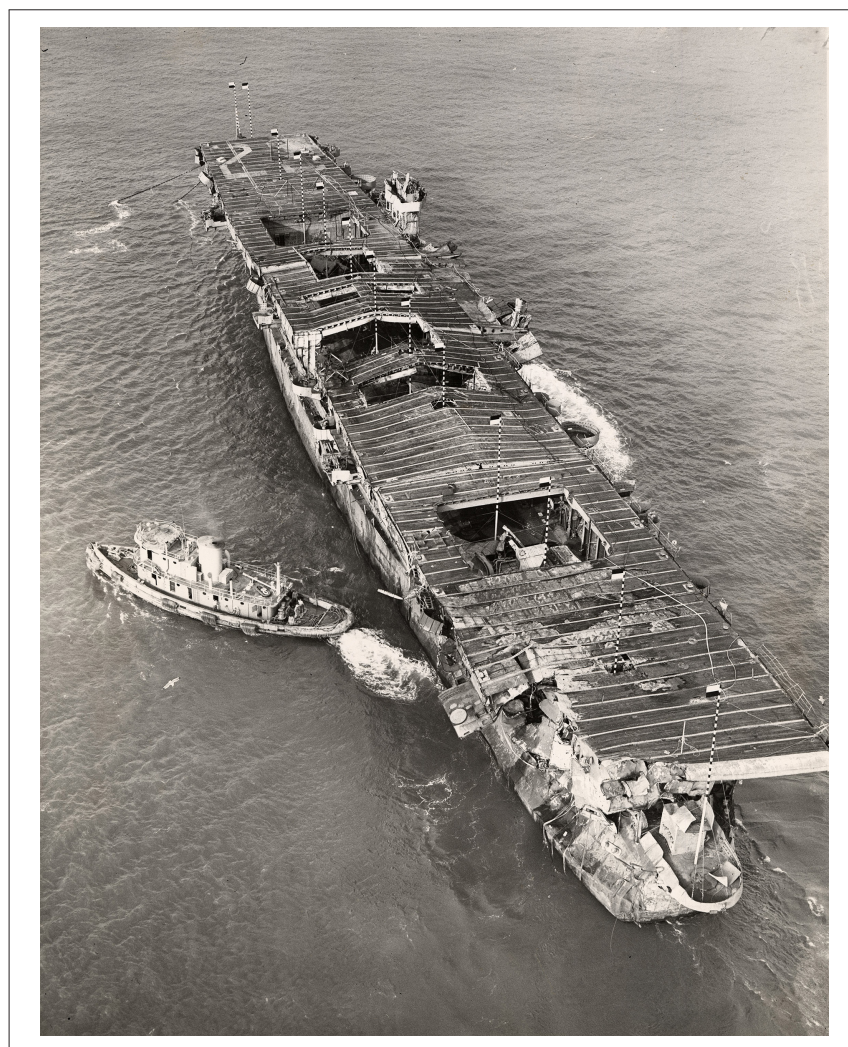

FIGURE 5 | The ex-USS Independence on San Francisco Bay, prior to being towed out for sinking (San Francisco Maritime National Historical Park).

to six foot sections of six inch salt water pipe to small bottles of scale, etc." They were placed on Independence "for ultimate sinking with that vessel because of lack of adequate storage facilities" (Bird, 1950a,b). Navy ships towed Independence to sea on January 25,1951 , and on January 26, detonated charges to sink

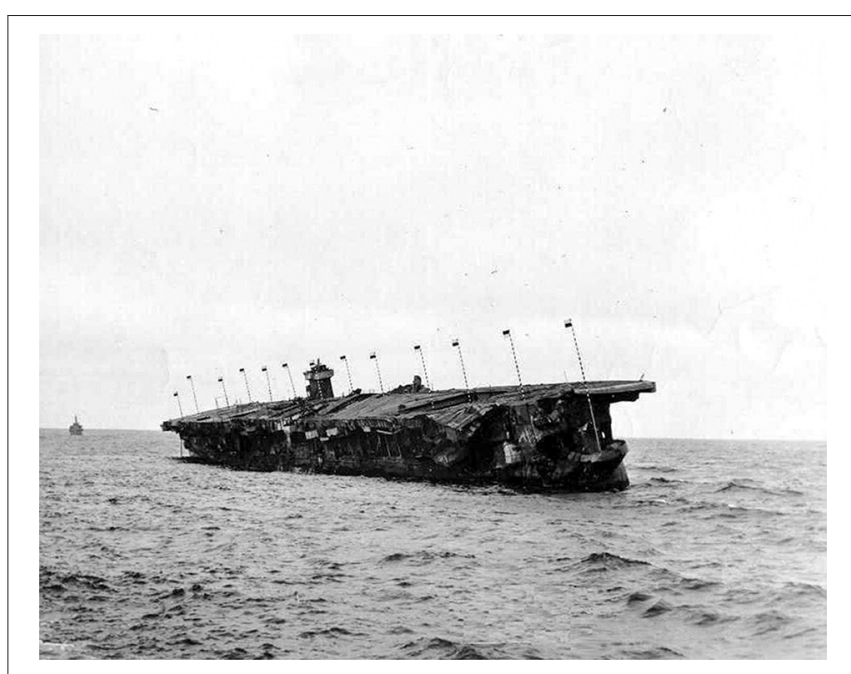

FIGURE 6 | Independence sinking (U.S. National Archives).

the ship (Figure 6) (ComWestSeaFron, 1951; Delgado, 2016b). The probable wreck site of Independence was located in 1990 at a depth of $\sim 900 \mathrm{~m}$ by the U.S. Geological Survey while mapping the Gulf of the Farallones National Marine Sanctuary, but the identity of the target was not confirmed (Chin and Ota, 2001).

\section{METHODS}

\section{Echo Ranger Survey Operations}

The Independence project in March 2014 utilized the $67^{\prime}$ research vessel Fulmar to carry the Boeing team and to escort the Echo Ranger AUV on overnight operations to the Independence site in the Monterey Bay National Marine Sanctuary (Figure 7). The Independence project was executed under a Cooperative Research and Development Agreement (CRADA) between NOAA Office of Oceanic and Atmospheric Research and the Boeing Company signed in 2013. The CRADA allows Boeing and NOAA to cooperate on technology demonstrations that address NOAA mission capabilities. It effectively provides NOAA with access to advanced undersea technologies like Echo Ranger and allows Boeing the opportunity to learn about NOAA missions and how to better address their technology requirements or offer better solutions (Delgado et al., 2016).

The Boeing Echo Ranger is a large diameter unmanned underwater vehicle (UUV). UUVs are often referred to as autonomous underwater vehicles or AUVs and in this paper "AUV" will be used. Echo Ranger is rectangular in form with a height and width of $4.2 \mathrm{ft}(1.3 \mathrm{~m})$ and length of 18.5 feet $(5.6 \mathrm{~m})$ (Figure 8). It weighs 10,500 lbs. (4545 kg) and can reach a depth of $10,000 \mathrm{ft}(3000 \mathrm{~m})$. While endurance is variable depending on payload and speed, the AUV's longest mission on this project lasted $\sim 32 \mathrm{~h}$. Its form, size and weight make it a very stable platform when submerged, ideal for conducting high resolution acoustic surveys. For navigation Echo Ranger carries an inertial navigation unit (INU) aided by a Doppler velocity log (DVL) and depth sensor. Ultra-short baseline (USBL) and long baseline line (LBL) transponders can be incorporated but were not on 


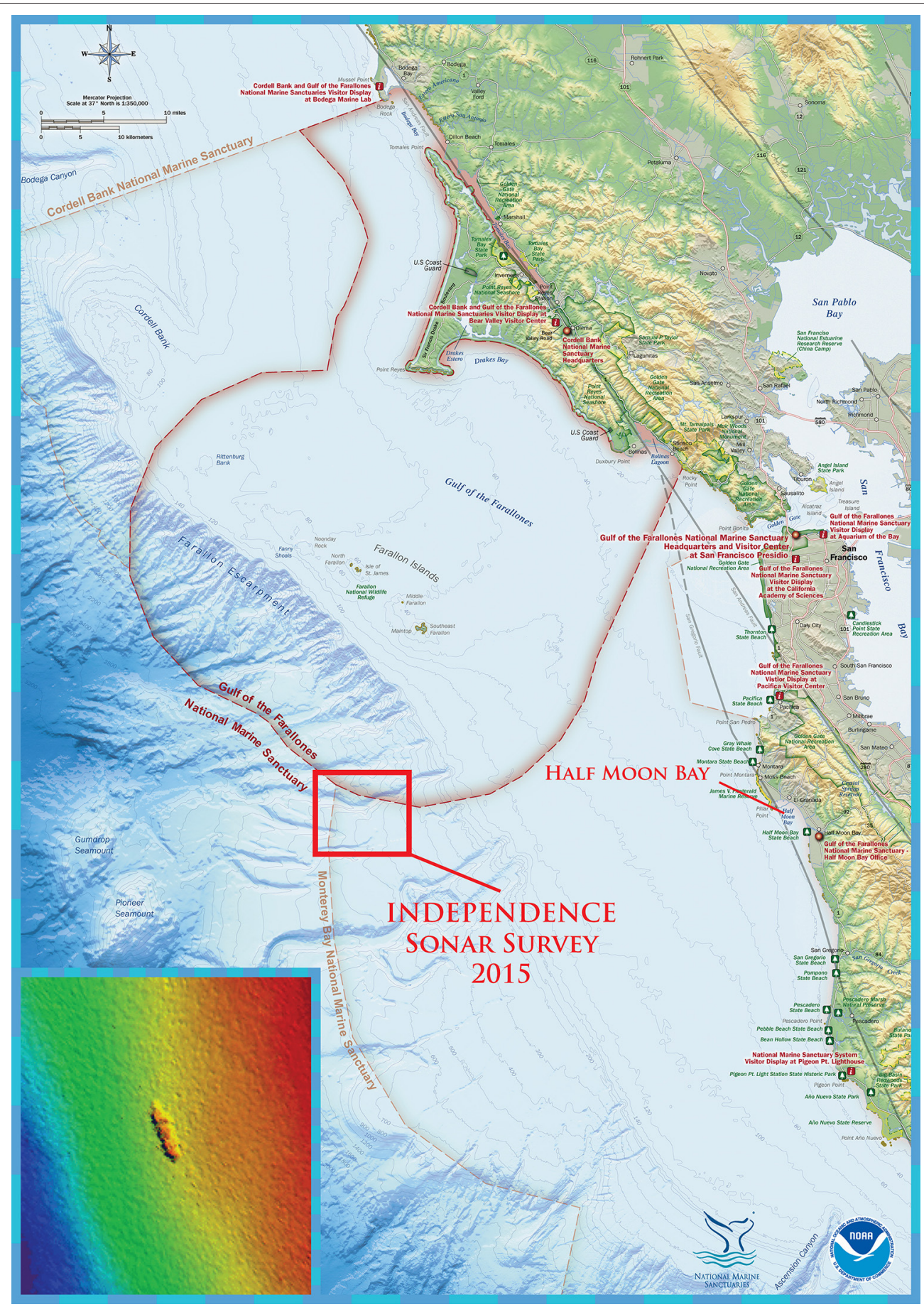

FIGURE 7 | Location of the wreck and survey area off the central California coast of the United States (NOAA/Robert Schwemmer).

this mission. GPS fixes are also possible to correct drift in the navigation. An acoustic modem allows communication of health and status updates to engineers on the boat during the mission.

For the Independence Project, Echo Ranger was equipped with Coda Octopus Echoscope ${ }^{(}$sonar. The Echoscope ${ }^{(}$is a volumetric sonar producing over 16,000 sonar beams per ping at a ping rate of up to 12 times per second. Coda Octopus provided a dual frequency Echoscope ${ }^{\odot}$ (375 and $610 \mathrm{kHz}$ ) which Boeing integrated into Echo Ranger at the front of the vehicle on the forward lower edge. The placement, at roughly a 45 degree angle, aimed the instrument looking forward and down.

The NOAA-Boeing mission accomplished the primary objective of verifying the location of Independence and confirmed its identification and orientation by imaging the entire flight deck 


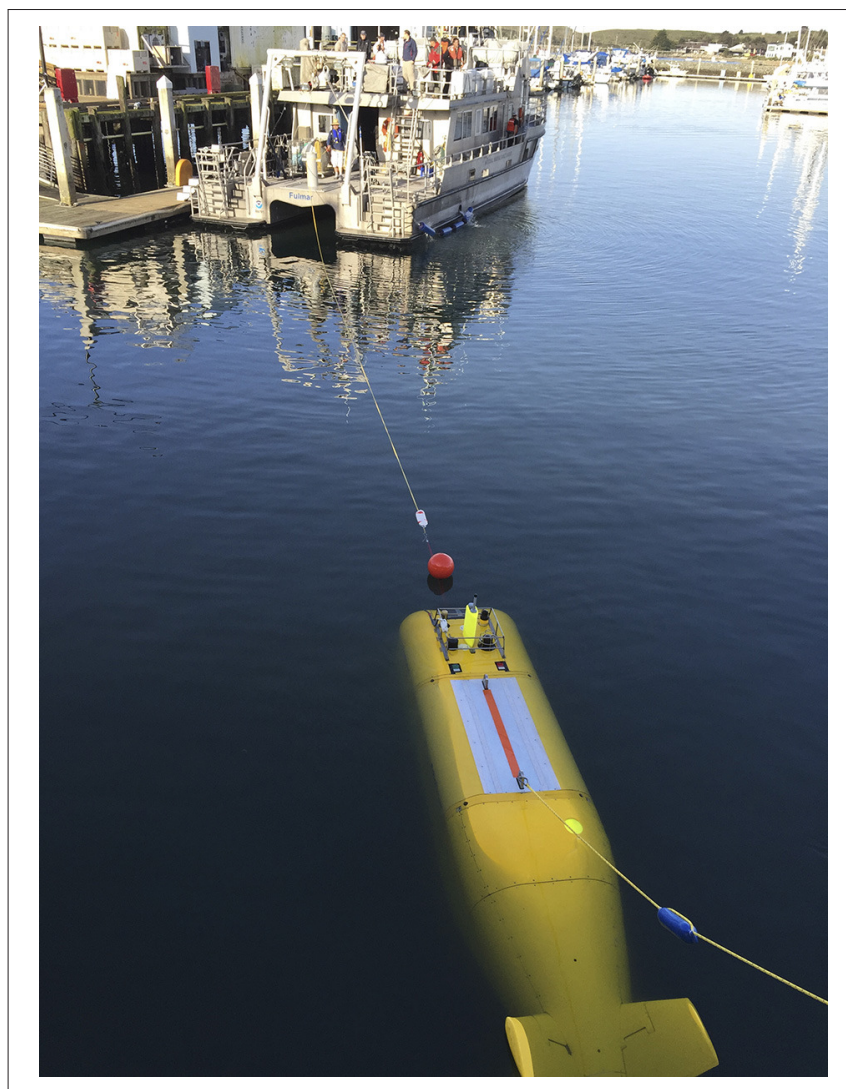

FIGURE 8 | The NOAA vessel Fulmar towing Echo Ranger out of harbor to commence survey operations. (NOAA/Robert Schwemmer).

and upper features of the wreck, but the sonar picked up very little of the sea floor or the side profile view of the ship.

The Echo Ranger was analyzed on the return to the surface with a handheld Polimaster PM1610B dosimeter to pick up ionizing radiation after the dive by the participants from UC Berkeley which found normal background measures of $0.09 \mu \mathrm{Sv}$. As water is an excellent radiation shield, it only extends several inches from contaminated materials, and the AUV stayed at least 100 feet from the wreck during the survey.

\section{RESULTS AND OBSERVATIONS}

Independence sits on a slope oriented with the bow pointed north at 340 degrees. It rests upright on the keel with a slight list to starboard. The hull measures $622 \mathrm{ft}(189.58 \mathrm{~m})$ in overall length and averages $76 \mathrm{ft}(23.16 \mathrm{~m})$ wide across the intact portions of the flight deck. The maximum width is $94 \mathrm{ft}(28.65 \mathrm{~m})$ measured across the flight deck and superstructure. The most prominent feature is the long and narrow flight deck with openings for the fore and aft aircraft elevators. Intact sections exhibit a series of horizontal lines indicating underlying structural elements. The amidships area is pierced by a number of openings with both irregular and straight edges that are also visible in historic photos taken during and just prior to scuttling. They are square and rectangular in shape exposing the hanger deck below. Some of these openings are discernable in the sonar images and are now

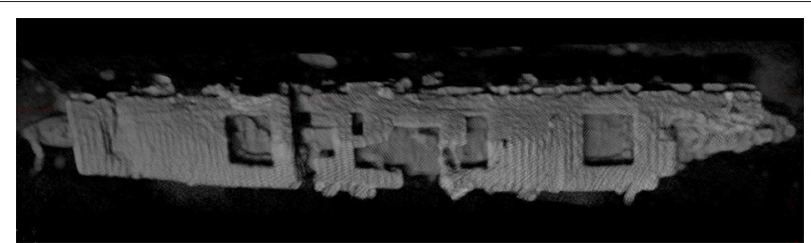

FIGURE 9 | Initial Sonar image of Independence (Boeing/NOAA).

part of larger holes in the deck amidships likely caused by collapse as the hull deteriorates. In addition, the sonar shows a gap in the hull just aft of the forward elevator and island which is where an expansion joint is located. Forward of the expansion joint the flight deck is intact while considerable collapse is evident aft of that point (Figure 9). Additional artifacts from Operation Crossroads may have also been left on and remain with Independence. For example, Independence left Kwajalein for the United States with "two-thirds of the unfuzed normal bomb allowance" on board (Berkhouse et al., 1984: 125). Unless a detailed survey and visual documentation takes place on the exterior and interior of the wreck, the archeological survival of this type of artifact can only be surmised (Delgado et al., 2016).

\section{DISCUSSION}

The importance of Independence resides not only in the context and social conditions leading to her construction and conversion, but extends to changing use and method of disposal, and how we view the wreck today and how we now view pollution threats in our oceans. Independence was deemed no longer useful to society more than 50 years ago, and sunk in 828.75 meters of water "beyond reach." The sinking of Independence was not an isolated event; most Crossroads target ships were sunk, with 85 going to the bottom between 1946 and 1948, and Independence, the last to be go in 1951, making a total of 86 of the 95 target vessels that were scuttled within the waters of the United States and the Republic of the Marshall Islands (Delgado et al., 1991; Delgado, 2016a: 173-174). This "out of sight out of mind" solution has proven to be a time limited option for hydrocarbon related threats.

The public perception of the sinking of these craft was that their "radiologically unsafe" status alone had sent them to the bottom. A 1949 article by columnist Drew Pearson in the Washington Post termed the scuttlings as a "major naval disaster" brought about by the radiation "from only two bombs" (Washington Post, February 18, 1949). The target ships left afloat after the tests were, as historian Paul Boyer notes, deemed a "pariah fleet of ghostly radioactive ships," and that perception of the 1940s and 1950s remains in the public mind to this day (Boyer, 1985:92). Most media articles about the 2015 Independence project referenced the ship's atomic history, with some terming it "radioactive."

Confirming that this wreck is the Independence, and an initial assessment showing that the wreck is intact, and does not contain a fuel or bunker related pollution threats provides a foundation for NOAA's Office of National Marine Sanctuaries to plan for further work to assess issues such as on board munitions, exposed 
or potentially accessible nuclear waste, and any residual radiation (which is unlikely) in the ship's hull and structure. The half-life of radioactive materials such as the cesium 137 and strontium 90 is about 30 years (Gale and Lax, 2013: 72-73). After 30 years, half the istotopes responsible for the initial contamination are transmuted into other non-radioactive isotopes. As it has been over 60 years since the Independence has been scuttled that means that less than a quarter of the radioactive isotopes remain (Greene, 2015).

Given the ongoing decline in ambient radiation in the ship as part of the natural decay of isotopes and radioisotopes (the alternate forms of elements with different atomic weights), the question is likely not what levels (if any) Independence has, but rather what are the levels, or if there are measurable levels from the material stowed deep inside the hulk in its engineering spaces and in concrete-filled 55-gallon steel drums. Given the seeming inaccessibility of those artifacts, that question may never be answered. This may make it challenging to ever change the public perception of wreck as a hazard.

However, previously inaccessible archival information examined as part of the project provided more specific information on the steps taken to prepare Independence as a receptacle for "nuclear waste" while also to some extent qualifying what that "waste" was as well as how it was prepared for permanent stowage in the sunken ship. That process also did not entail simply throwing waste into a compartment and then shooting at the hulk until it sank. Deep inside in the ship, the compartment built to contain the heavy engineering plant was cleared, and this was where waste barrels into which concrete was poured as a shield, were stowed. Archives and anecdotes alone do not make for a solid assessment, only empirical facts

\section{REFERENCES}

Berkhouse, L., Davis, S. E., Gladeck, F. R., Hallowell, J. H., Jones, C. B., Martin, E. J., et al. (1984). Operation Crossroads, 1946. Washington, DC: Defense Nuclear Agency.

Bird, J. L. (1950a). Confidential Memorandum from Commander, San Francisco Naval Shipyard to Chief, Bureau of Ships, Subject: Samples from Crossroads Vessels, Disposal of, September 1.

Bird, J. L. (1950b). Letter from Laboratory Director, U.S. Naval Radiological Defense Laboratory, San Francisco Naval Shipyard, to Area Manager, U.S. Atomic Energy Commission, Berkeley Area Office, December 11.

Boyer, P. (1985). By the Bomb's Early Light: American Thought and Culture at the Dawn of the Atomic Age. New York, NY: Pantheon.

Bureau of Ships (1946). Technical Inspection Report, USS Independence (CVL22), Test Able, Operation Crossroads. Washington, DC: Director of Ship Material, Joint Task Force One.

Chin, J. L., and Ota, A. (2001). "Disposal of dredges material and other waste on the continental shelf and slope," in Beyond the Golden Gate: Oceanography, Geology, Biology and Environmental Issues in the Gulf of the Farallones, ed H. A. Karl (Denver, CO: United States Geological Survey), 62-65.

ComWestSeaFron. (1951). Operation Sea Order, T.F. 98.5, January 16.

Delgado, J. P. (2016a). After crossroads: the fate of the atomic bomb target fleet. J. Marit. Archaeol. 11, 25-31. doi: 10.1007/s11457-016-9154-7

Delgado, J. P. (2016b). Post-crossroads history of the ex-USS independence: recently declassified documents and images. J. Marit. Archaeol. 11, 35-126. doi: 10.1007/s11457-016-9158-3

Delgado, J. P., Elliott, K., Cantelas, F., and Schwemmer, R. V. (2016). Initial archaeological survey of the ex-USS independence gathered by survey and physical inspection. Plans are being prepared for a detailed ROV inspection of the wreck in 2016. This detailed characterization and photographic survey, will include penetration of accessible interior spaces, and attempts to measure ambient radiation if it can be detected. This type of effort is key when dealing with any wreck thought to be a hazard whether from oil, munitions or radioactive wastes, and in the case of Independence, an essential next step.

\section{AUTHOR CONTRIBUTIONS}

All the authors were part of either the mission planning and execution of this assessment of the USS Independence. KE wrote her dissertation on the USS Independence providing critical background information on the history and use of the vessel prior to her scuttling. JD is the Director of the NOAA Maritime Heritage Program in the Office of National Marine Sanctuaries and is an expert on WWII vessels, FC was critical in developing the partnership with Boeing, and RS was a critical member of the on-board team and provided additional background research. LS has become an expert on the assessment of potentially polluting wrecks and was part of the early planning on this mission and placing this assessment in the broader context of pollution risk in US waters.

\section{FUNDING}

Funds for this effort were from base appropriations for the National Oceanic and Atmospheric Administration. Boeing, Inc. provided their autonomous vehicle and support team as in-kind support for the project.

(CVL-22). J. Marit. Archaeol. 11, 9-24. doi: 10.1007/s11457-0169152-9

Delgado, J. P., Lenihan, D. J., and Larry E. M. (1991). The Archaeology of the Atomic Bomb: A Submerged Cultural Resources Assessment of the Sunken Fleet of Operation Crossroads at Bikini and Kwajalein Atoll Lagoons. Santa Fe: National Park Service.

Gale, R. P. and Lax, E. (2013). Radiation. New York, NY: Vintage.

Greene, K. (2015). Radiation Safety for Sunken Ship Archaeology. Available online at: http://newscenter.lbl.gov/2015/07/07/radiation-safety-for-sunkenship-archaeology/

Lambert, J. G. (2015). USS Independence CVL-22: A War Diary of the Nation's First Dedicated Night Carrier, a WWII History of the "Mighty-I" Her Air Groups of Her Crew, NP: printed for J.G. Lambert.

Shurcliff, W. A. (ed.). (1946). Technical Report: Operation Crossroads. Washington, DC: Commander, Joint Task Force One.

Shurcliff, W. A. (1947). Bombs at Bikini: The Official Report of Operation Crossroads New York, NY: W.H. Wise.

Conflict of Interest Statement: The authors declare that the research was conducted in the absence of any commercial or financial relationships that could be construed as a potential conflict of interest.

Copyright (c) 2016 Delgado, Symons, Elliott, Cantelas and Schwemmer. This is an open-access article distributed under the terms of the Creative Commons Attribution License (CC BY). The use, distribution or reproduction in other forums is permitted, provided the original author(s) or licensor are credited and that the original publication in this journal is cited, in accordance with accepted academic practice. No use, distribution or reproduction is permitted which does not comply with these terms. 